\title{
KAJIAN LALU-LINTAS DI PERLINTASAN SEBIDANG RESMI TIDAK DI JAGA JALAN RAYA BEJI DAN JALAN YONKAV KABUPATEN PASURUAN
}

\author{
${ }^{1}$ Dhina Setyo Oktaria \\ ${ }^{2}$ Frice Lahmuddin Desei \\ ${ }^{3}$ Arief Darmawan \\ ${ }^{1}$ Dosen Politeknik Perkeretaapian Indonesia Madiun, dhina@ppi.ac.id, \\ 081804182791) \\ ${ }^{2}$ Dosen Jurusan Teknik Sipil, Fakultas Teknik, Universitas Negeri \\ Gorontalo, fricedesei@ung.ac.id, 081244395100) \\ ${ }^{3}$ Dosen Politeknik Perkeretaapian Indonesia Madiun (arief@ppi.ac.id, \\ 085733146282)
}

\begin{abstract}
ABSTRAK
Perlintasan sebidang yang tidak dikelola dengan baik akan menimbulkan permasalahan. Kabupaten Pasuruan di Jalan Yonkav arah Beji dan Bangil serta Jalan Raya Beji arah Surabaya dan Pasuruan terdapat perlintasan resmi tidak dijaga yang dari tahun 2019 s.d 2021 terjadi beberapa kecelakaan lalu-lintas. Tujuan penelitian ini untuk mengetahui arus lalu-lintas di perlintasan sebidang tidak resmi dijaga jalan raya beji dan jalan yonkav sehingga dapat memberikan masukan untuk pembuat kebijakan dalam mengurangi terjadinya kecelakaan lalu-lintas di lokasi tersebut. Penelitian ini menggunakan metode penelitian kuantitatif dan kualitatif. Survei dilakasanakan pada pagi hari pukul 06.00 s.d 10.00, siang hari pukul 10.00 s.d 14.00 dan sore hari pukul $14.00 \mathrm{~s}$,d 16.00. Hasil penelitian didapatkan bahwa untuk Jalan Raya Beji arah Pasuruan pagi hari jumlah kendaraan total 866,8 smp/jam dengan V/C sebanyak 0,58 dan nilai LOS di level C. Jalan Raya Beji arah Surabaya paling padat pada pagi hari jumlah kendaraan total $1053 \mathrm{smp} / \mathrm{jam}$ dengan V/C sebanyak 0,70 dan LOS di level C. Jalan Yonkav arah Bangil dan Beji untuk LOS pagi, siang ataupun sore berada di Level A dan di peroleh solusi jangka pendek, jangka menengah dan jangka panjang.
\end{abstract}

Kata Kunci: Perlintasan sebidang resmi tidak dijaga, Keselamatan, Jalan Yonkav, Jalan Raya Beji.

\begin{abstract}
Level crossings that are not managed properly will cause problems. Pasuruan Regency on Jalan Yonkav towards Beji and Bangil and Jalan Raya Beji towards Surabaya and Pasuruan there are official unguarded crossings from 2019 to 2021 several traffic accidents. The purpose of this study is to determine the flow of traffic at level crossings that are not officially guarded by Jalan Beji and Jalan Yonkav so that it can provide input for policymakers in reducing the occurrence of traffic accidents at these locations. This research uses quantitative and qualitative research methods. The survey was conducted in the morning from 06.00 to 10.00 , in the afternoon from 10.00 to 14.00 , and in the afternoon from 14.00 to 16.00 . The results showed that for Jalan Raya Beji towards Pasuruan in the morning, the total number of vehicles was 866.8 passenger car units per hour with a V/C of 0,58 and the LOS value was at level C. Jalan Raya Beji towards Surabaya was the most congested in the morning; the total number of vehicles was 1053 passenger car units per hour
\end{abstract}


with a V/C of 0.70 and LOS at level C. Jalan Yonkav towards Bangil and Beji for the morning, afternoon, or evening LOS are at Level A, and short, medium, and long-term solutions are obtained.

Key word: Unattended level crossing, Safety, Yonkav Road, Beji Highway

\section{PENDAHULUAN}

Perlintasan sebidang menjadi masalah bagi hampir semua negara di dunia ini. Hal ini dikarenakan jika tidak di kelola dengan baik terkait geometri maupun regulasi maka perlintasan sebidang kereta api dengan jalan raya rawan menimbulkan terjadinya kecelakaan jalan raya. Di Indonesia terdapat tiga jenis perlintasan sebidang kereta api yaitu perlintasan sebidang kereta api resmi dijaga, perlintasan sebidang kereta api resmi tidak dijaga dan perlintasan sebidang kereta api liar (tidak resmi dan tidak dijaga). Pada saat ini tidak tercatat secara pasti seluruh perlintasan sebidang di Indonesia. Berdasarkan PM No 94 Tahun 2018 secara tersirat di bagian lampiran peraturan disebutkan mengenai jumlah perlintasan sebidang berdasarkan wilayah kerjanya atau sesuai pembagian daerah operasi PT KAI di Indonesia. [1]. Selain PT KAI selaku BUMN Indonesia yang menyelenggarakan prasarana dan sarana di bidang perkeretaapian, untuk perlintasan sebidang juga terdapat kewenangan Dinas Perhubungan baik Dinas Perhubungan Propinsi ataupun Dinas Perhubungan kota/kabupaten yang berwenang terhadap perlintasan sebidang kereta api.

Di Kabupaten Pasuruan terdapat jalan umum yang di bagi menjadi empat yaitu jalan nasional, jalan propinsi, jalan kabupaten dan jalan kota. Terdapat jalan yang sebidang dengan perlintasan resmi tidak dijaga di wilayah jalan nasional yaitu di antara pertigaaan antara Jalan Yonkav yang merupakan jalan kabupaten dengan jalan Raya Beji yang merupakan jalan nasional. Berikut disajikan gambar layout untuk perlintasan sebidang resmi tidak dijaga tersebut :

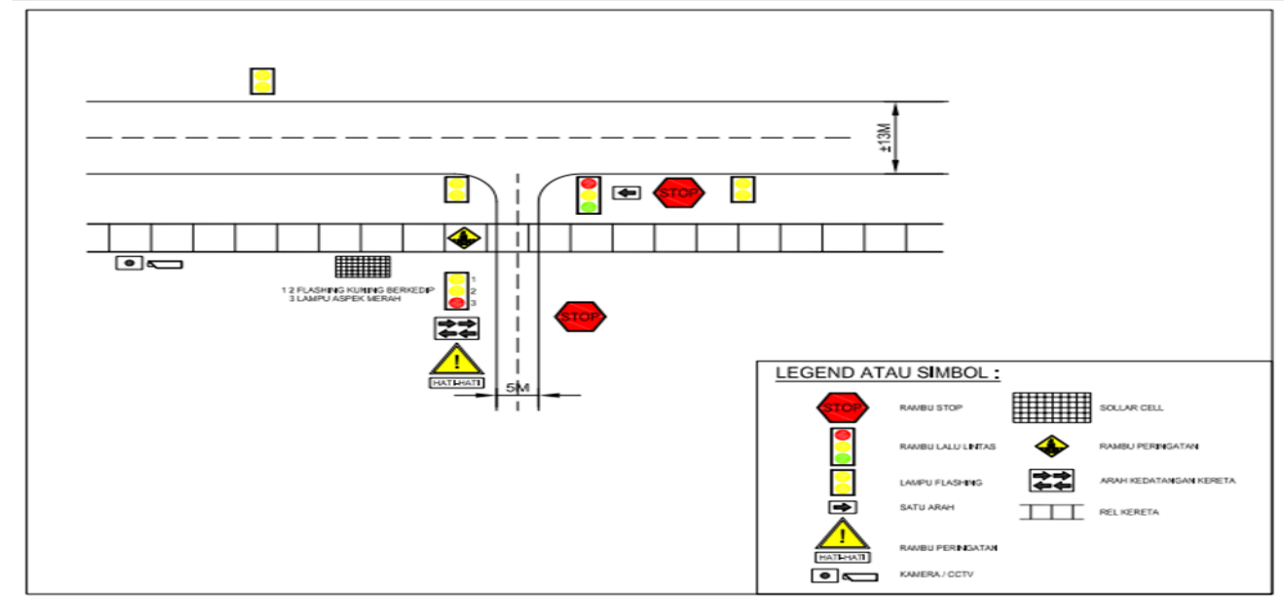

Gambar 1. Layout Perlintasan resmi sebidang tidak dijaga dengan jalan raya

Berdasarkan gambar 1 di atas, maka terdapat dua jalan yaitu Jalan Raya Beji (arah Surabaya dan arah Pasuruan), serta Jalan Yonkav (arah Bangil dan arah Beji). Untuk jalan Raya Beji arah Surabaya ataupun arah Pasuruan termasuk dalam lingkup jalan nasional. Definisi dari jalan nasional adalah jalan arteri dan jalan kolektor dalam sistem jaringan jalan utama yang menghubungkan antar ibukota provinsi, dan jalan strategis nasional, serta jalan tol. Jalan Yonkav ke arah Bangil 
ataupun ke arah Beji merupakan jalan kabupaten. Hal ini berdasarkan Keputusan Bupati Pasuruan No 950/397/HK/424.014/2017 tentang Penetapan Status Ruasruas jalan Sebagai Jalan Kabupaten di Kabupaten Pasuruan. [2]. Definisi dari jalan kabupaten adalah jalan lokal dalam sistem jaringan jalan primer yang menghubungkan ibukota kabupaten dengan ibukota kecamatan, antar ibukota kecamatan, ibukota kabupaten dengan pusat kegiatan lokal, antarpusat kegiatan lokal, serta jalan umum dalam sistem jaringan jalan sekunder dalam wilayah kabupaten, dan jalan strategis kabupaten.[3]

Berdasarkan penelitian terdahulu di JPL 325 lamongan dimana terdapat 152 sampel responden yang mengendarai sepeda motor di perlintasan tersebut didapatkan data bahwa hal yang berkaitan dengan terjadinya kecelakaan adalah apabila pengendara membawa barang bawaan berlebih, tetapi hanya menyumbang presentase keterkaitan kecil yaitu sebesar 6,25\%. [4]. Sehingga faktor penyebab kecelakaan perlu mendapatkan penelitian lebih lanjut untuk menentukan faktorfaktor apa saja penyebabnya. Berikut disajikan data beberapa kecelakaan lalu-lintas di perlintasan sebidang resmi tidak dijaga di jalan raya beji dan jalan yonkav tersebut antara lain :

Tabel 1. Kecelakaan lalu-lintas di perlintasan sebidang resmi tidak dijaga

\begin{tabular}{lll}
\hline \multicolumn{1}{c}{ Tanggal Kejadian } & \multicolumn{1}{c}{$\begin{array}{c}\text { Kendaraan yang } \\
\text { tertemper }\end{array}$} & \multicolumn{1}{c}{ Korban } \\
\hline 9 Januari 2019 & Mobil pribadi & Lima orang meninggal ditempat \\
6 Mei 2019 & Mobil pribadi & $\begin{array}{l}\text { Empat penumpang bisa diselamatkan } \\
\text { Penumpang dapat diselamatkan }\end{array}$ \\
4 Oktober 2019 & Truk & $\begin{array}{l}\text { Satu penumpang meninggal di tempat, } \\
\text { dua orang penumpang luka berat }\end{array}$ \\
20 September 2020 & Mobil Pribadi & Satu orang meninggal di tempat \\
11 Februari 2021 & Sepeda Motor & Lima orang terluka parah \\
12 Februari 2021 & Mobil Pribadi &
\end{tabular}

Sumber : berita di koran [5]

Keadaan ini diperparah dengan jarak untuk memutar kendaraan yang sangat dekat dengan perlintasan kereta api, sehingga mengakibatkan pengendara di jalan raya tidak mempunyai banyak waktu untuk dapat menghentikan kendaraannya ataupun tidak mempunyai banyak waktu untuk dapat mengamati kedatangan kereta api yang akan melintasi perlintasan tersebut. Keselamatan dalam berlalu-lintas adalah hal utama yang ingin diperoleh oleh pengguna jalan. Agar dapat mengurangi terjadinya kecelakan di perlintasan sebidang resmi tidak dijaga tersebut maka peneliti melakukan penelitian tentang Kajian Lalu-lintas di Perlintasan Sebidang Resmi Tidak di Jaga di Perlintasan Sebidang Jalan Raya Beji dan Jalan Yonkav di Kabupaten Pasuruan.

\section{TINJAUAN PUSTAKA}

\section{Tingkat Pelayanan Jalan (Level Of Service)}

Tingkat pelayanan jalan didefinisikan sejauh mana kemampuan jalan menjalankan fungsinya. Atas dasar itu pendekatan tingkat pelayanan dipakai sebagai indikator tingkat kinerja jalan. Level of service merupakan suatu ukuran kualitatif yang menggunakan kondisi operasi lalu-lintas pada suatu potongan jalan. Dengan kata lain tingkat pelayanan jalan adalah ukuran yang menyatakan kualitas pelayanan yang disediakan oleh suatu jalan dalam kondisi tertentu. Nilai tingkat pelayanan jalan (level of service) dapat dijadikan tolak ukur mengenai keterkaitan antara kecepatan, kepadatan, dan tingkat pelayanan arus lalulintas.[6]. Adapun rumus LOS ini adalah : 
$\operatorname{LOS}=\mathrm{V} / \mathrm{C}$

Dimana :

LOS = level Of Service

$\mathrm{V} \quad=$ volume lalu-lintas $(\mathrm{smp} / \mathrm{jam})$

$\mathrm{C} \quad=$ kapasitas actual (smp/jam)

Tabel 2. Standar Tingkat Pelayanan Jalan

\begin{tabular}{ccl}
\hline V/C & Tingkat pelayanan Jalan & \multicolumn{1}{c}{ Keterangan } \\
\hline 0.00 s.d 0.19 & A & Arus lancar, volume rendah, kecepatan tinggi \\
0.20 s.d 0.44 & B & Arus stabil, kecepatan terbatas, volume sesuai untuk luar kota \\
0.45 s.d 0.74 & C & $\begin{array}{l}\text { Arus stabil, kecepatan dipengaruhi oleh lalu-lintas, volume sesuai } \\
\text { untuk jalan kota }\end{array}$ \\
0.75 s.d 0.84 & D & $\begin{array}{l}\text { Mendekati arus tidak stabil, kecepatan rendaj } \\
\text { Arus tidak stabil, kecepatan rendah, volume padat atau mendekati }\end{array}$ \\
$0.85 . \mathrm{d} 1.00$ & $\mathrm{E}$ & kapasitas \\
& & Arus yang terhambat, kecepatan rendah, volume diatas kapasitas \\
\hline
\end{tabular}

Sumber : [7]

\section{Pemasangan Rambu Lalu-lintas}

Bersumber pada persyaratan teknis dari Direktorat Jenderal Perhubungan Darat Nomor SK/407/AJ.401/DRJD/2018 [8] sehingga didapatkan jenis-jenis rambu lalu-lintas yang ditempatkan pada perlintasan sebidang. Berikut disajikan kelengkapan rambu lalulintas pada perlengkapan sebidang tidak berpalang pintu pada jalan dua lajur dua arah dengan jalur tunggal kereta api :

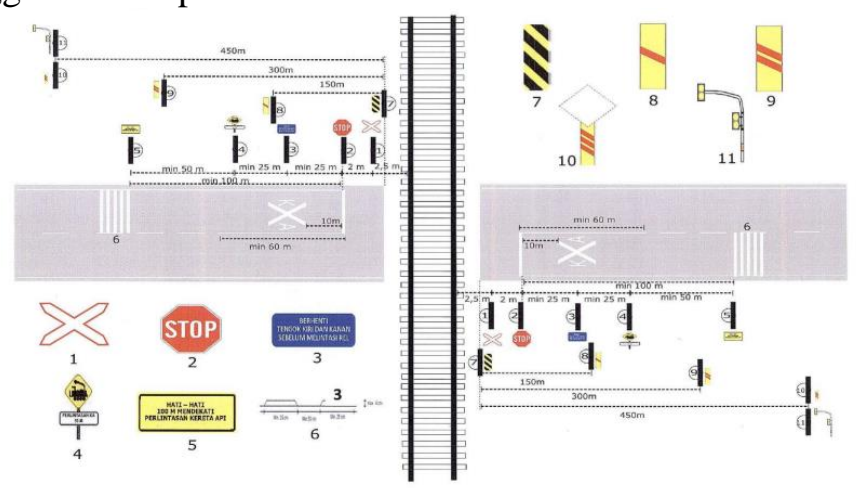

Gambar 2. Pemasangan Perlengkapan Jalan Pada Perlintasan Sebidang Tanpa Pintu Pada Jalan Dua Lajur Dua Arah Dengan Jalur Tunggal Kereta Api

\section{Kereta Api yang Melintasi Pasuruan}

Bersumber pada informasi grafik perjalanan kereta api (Gapeka) PT KAI berlaku mulai 10 Februari 2021 didapatkan data kereta api yang melintas di Pasuruan antara lain: KA Ranggajati, KA Mutiara Timur, KA Wijayakusuma serta KA Logawa. Tidak hanya itu terdapat pula kereta api commuter line dari Stasiun Surabaya kota sampai dengan Stasiun Pasuruan.[9]

\section{METODE PENELITIAN}

Dalam penelitian ini peneliti memakai metode penelitian kuantitatif dengan melaksanakan studi lapangan dan pula metode kualitatif dengan bersumber pada informasi sekunder. Adapun informasi dari tata cara penelitian kuantitatif berbentuk data- data yang didapatkan di lokasi penelitian dengan melaksanakan survei lapangan berupa data yang terkait dengan volume kendaraan lintas harian di Jalan Raya Beji (arah Surabaya dan Pasuruan) dan volume lalu- lintas harian di Jalan Yonkav (arah Bangil dan Beji). Untuk data sekunder berbentuk data-data 
tertulis yang didapatkan peneliti dari Dinas Perhubungan Kabupaten Pasuruan, internet, penelitian sebelumnya serta data dari peraturan perundang- undangan dan literatur yang terkait dengan penelitian.

Untuk pembagian waktu survei terhadap kendaraan yang melintasi perlintasan sebidang resmi tidak dijaga di Jalan Raya Beji serta Jalan Yonkav Kabupaten Pasuruan di buat menjadi 3 yakni pada waktu pagi, dimana pada jamjam tersebut umumnya digunakan oleh masyarakat untuk melaksanakan aktivitas sehari-hari missal berangkat ke kantor maupun menuju ke sekolahan, kemudian waktu siang dimana jam-jam tersebut umumnya digunakan utnuk waktu istirahat siang serta yang terakhir pada waktu sore pada jam-jam tersebut umumnya digunakan oleh masyarakat untuk pulang kantor atau pulang sekolah. Berdasarkan tabel di atas maka pembagian waktu pagi hari pada pukul 06.00 s.d pukul 10.00, kemudian siang hari pada pukul 10.00 s.d pukul 14.00 WIB dan terakhir sore hari pada pukul 14.00 s.d 18.00 .

Pengolahan data dilaksanakan dengan mengolah data primer yang didapatkan dari survei lapangan untuk kemudian di hitung dengan rumus. Serta mengolah data sekunder untuk kemudian di analisis dengan data primer sehingga diperoleh hasil penelitian dan kesimpulan dari penelitian.

\section{Hasil}

\section{HASIL \& PEMBAHASAN}

Penelitian dilaksanakan di ruas jalan beji raya arah ke Surabaya dan juga arah ke Pasuruan, selain itu juga di jalan Yonkav arah Beji dan juga arah Bangil, Berikut adalah gambar kondisi lalu-lintas di perlintasan sebidang resmi tidak di jaga tersebut :

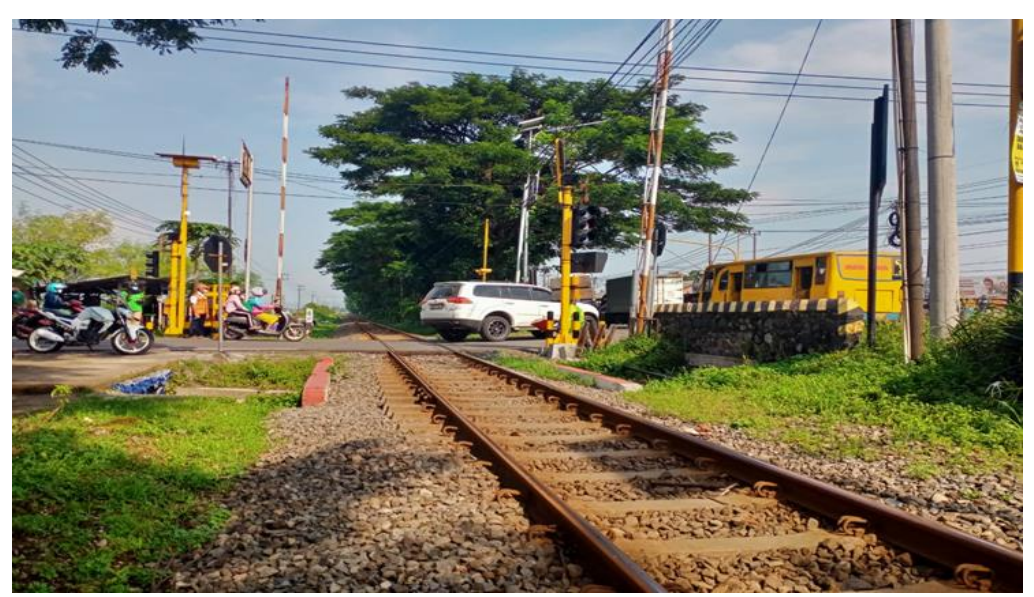

Gambar 2. Perlintasan Sebidang Resmi Tidak Dijaga

Berdasarkan gambar 2. di atas maka rambu-rambu lalu-lintas yang terpasang terdiri dari rambu tanda stop, rambu lampu lalu-lintas, rambu lampu flashing, tanda penunjuk arah satu arah, rambu peringatan awas ada rel kereta jalan tunggal tidak dijaga, kamera cctv, solar cell, rambu peringatan, rambu arah kedatangan kereta danrambu rel kereta.

Berdasarkan penelitian didapatkan data bahwa panjang Jalan Raya Beji arah Surabaya adalah $1.11 \mathrm{~km}$ dengan tipe jalan tipe jalan 4/2 UD, yaitu jalan empat lajur dua arah tak terbagi (tanpa ada median). Lebar jalan adalah 13 meter persegi. Jalan ini merupakan jalan menuju ke perlintasan sebidang resmi tidak dijaga 
sebelum memasuki Jalan Yonkav yang menuju ke arah Beji. Kondisi jalan baik, kondisi jalan dengan rel baik/datar. Rambu lalu-lintas yang terdapat di ruas jalan ini adalah rambu lampu lalu-lintas, rambu stop, rambu peringatan ada jalan rel single track.

Kemudian untuk Jalan Raya Beji arah Pasuruan panjangnya adalah $2.40 \mathrm{~km}$ dengan tipe jalan tipe jalan 4/2 UD, yaitu jalan empat lajur dua arah tak terbagi (tanpa ada median). Lebar jalan adalah 13 meter persegi. Jalan ini merupakan jalan menuju ke perlintasan sebidang resmi tidak dijaga sebelum memasuki Jalan Yonkav yang menuju kearah Beji. Kondisi jalan baik, kondisi jalan dengan rel baik/datar. Rambu lalu-lintas yang terdapat di ruas jalan ini adalah rambu lampu lalu-lintas dan rambu stop berupa suara Early Warning System (EWS).

Panjang jalan Yonkav arah Beji adalah $1.16 \mathrm{~km}$ dengan tipe jalan tipe jalan 2/2 UD, yaitu jalan dua lajur dua arah tak terbagi (tanpa ada median). Lebar jalan adalah 5 meter persegi. Perlintasan sebidang resmi tidak dijaga yang terletak di Jalan Yonkav arah Beji merupakan perlintasan menuju kearah Jalan Raya Beji. Kondisi jalan baik, kondisi jalan dengan rel baik/datar. Rambu lalu-lintas yang terdapat di ruas jalan ini adalah rambu awas hati-hati ada kereta api, rambu arah penunjuk kedatangan kereta api, rambu lampu lalu-lintas, lampu solar cell dan rambu peringatan jalan kereta api jalur tunggal.

Panjang Jalan Yonkav arah Bangil adalah $1.16 \mathrm{~km}$ dengan tipe jalan tipe jalan 2/2 UD, yaitu jalan dua lajur dua arah tak terbagi (tanpa ada median). Lebar jalan adalah 5 meter persegi. Perlintasan sebidang resmi tidak dijaga yang terletak di Jalan Yonkav arah Bangil merupakan perlintasan menuju kearah bangil. Kondisi jalan baik, kondisi jalan dengan rel baik/datar. Rambu lalu-lintas yang terdapat di ruas jalan ini adalah rambu lampu lalu-lintas, rambu stop, rambu peringatan ada jalan rel jalur tunggal.

Dalam MKJI, nilai arus lalu-lintas (Q) memcerminkan komposisi lalu-lintas, berdasarkan arus dalam satuan mobil penumpang (smp). Semua nilai arus lalu lintas, (per arah dan total) diubah menjadi satuan mobil penumpang (smp) dengan menggunakan ekuvalensi mobil penumpang yang diturunkan secara empiris untuk tipe kendaraan berikut :

a. Kendaraan tingan (LV), termasuk mobil penumpang, mini bus, pick up, truk kecil dan jeep. Secara umum merupakan semua kendaraan beroda 4 termasuk di dalamnya adalah truk kecil.

b. Kendaraan berat (HV), termasuk truk dan bus. Secara umum merupakan semua kendaraan beroda lebih dari 4.

c. Sepeda motor (MC), merupakan kendaraan beroda 2.[10]

Berdasarkan hasil survei di lapangan maka di dapatkan data jenis kendaraan yang melintas di Jalan Raya Beji antara lain :

Tabel 3. Data Jenis Kendaraan di Jalan Raya Beji

\begin{tabular}{|c|c|c|c|c|}
\hline \multirow{2}{*}{ Jenis Kendaraan } & \multicolumn{2}{|c|}{ Jalan Raya Beji arah Surabaya } & \multicolumn{2}{|c|}{ Jalan Raya Beji arah Pasuruan } \\
\hline & Jumlah & Presentase & Jumlah & Presentase \\
\hline Sepeda Motor & 3362 & 34 & 2799 & 41 \\
\hline Mobil & 4448 & 46 & 1391 & 20 \\
\hline Bus dan Truk & 1961 & 20 & 2687 & 39 \\
\hline Total & 9771 & 100 & 6877 & 100 \\
\hline
\end{tabular}


Sedangkan untuk data jenis kendaraan yang melintas di Jalan Yonkav antara

Tabel 4. Data Jenis Kendaraan di Jalan Yonkav

\begin{tabular}{|c|c|c|c|c|}
\hline \multirow{2}{*}{ Jenis Kendaraan } & \multicolumn{2}{|c|}{ Jalan Yonkav arah Beji } & \multicolumn{2}{|c|}{ Jalan Yonkav arah Bangil } \\
\hline & Jumlah & Presentase & Jumlah & \\
\hline Sepeda Motor & 997 & 77 & 841 & 73 \\
\hline Mobil & 277 & 21 & 285 & 25 \\
\hline Bus dan Truk & 29 & 2 & 23 & 2 \\
\hline Total & 1303 & 100 & 1149 & 100 \\
\hline
\end{tabular}

Berdasarkan rumus yang didapat dari Manual Kapasitas Jalan Indonesia (MKJI 1997) maka diperoleh :

$\mathrm{C}=\mathrm{C} 0 \times \mathrm{Fcw} \times \mathrm{FCsp} \times \mathrm{FCsf} \times \mathrm{FCcs}$

dimana:

$\mathrm{C} \quad=$ Kapasitas ( $\mathrm{smp} / \mathrm{jam})$

$\mathrm{C} 0=$ Kapasitas dasar (smp/jam)

$\mathrm{Fcw}=$ Faktor penyesuaian akibat lebar jalan lalu lintas

FCsp $=$ Faktor penyesuaian akibat pemisah arah

FCsf $=$ Faktor penyesuaian akibat hambatan samping

FCcs $=$ Faktor penyesuaian untuk ukuran kota

Untuk perhitungan volume lalu lintas yang melintasi Jalan Raya Beji dan Jalan Yonkav didapatkan hasil :

Tabel 5. Data volume lalu lintas yang melintasi Jalan Raya Beji dan Jalan Yonkav

\begin{tabular}{cccccc}
\hline Nama Jalan & Arah & $\begin{array}{c}\text { Pagi } \\
\text { (smp/jam) }\end{array}$ & $\begin{array}{c}\text { Siang } \\
(\text { smp/jam })\end{array}$ & $\begin{array}{c}\text { Sore } \\
(\text { smp/jam })\end{array}$ & $\begin{array}{c}\text { Kapasitas Jalan } \\
\text { (smp/jam })\end{array}$ \\
\cline { 1 - 5 } JL. Raya Beji & Pasuruan & 866,8 & 497,2 & 402,4 & 1500,00 \\
& Surabaya & 1053 & 693 & 660,3 & 1500,00 \\
\multirow{2}{*}{ Jl. Yonkav } & Bangil & 85 & 52 & 65,6 & 722,68 \\
& Beji & 95,1 & 49,1 & 70 & 722,68 \\
\hline
\end{tabular}

Berdasarkan survey di lapangan maka didapatkan data mengenai tingkat pelayanan jalan atau Level Of Service (LOS) di Jalan Beji Raya dan Jalan Yonkav maka didapatkan data bahwa :

Tabel 6. Tingkat pelayanan jalan atau Level Of Service (LOS)

\begin{tabular}{ccccccc}
\hline \multirow{2}{*}{ Nama Jalan } & \multicolumn{2}{c}{ Pagi } & \multicolumn{2}{c}{ Siang } & \multicolumn{2}{c}{ Sore } \\
& V/C & LOS & V/C & LOS & V/C & LOS \\
\hline \multirow{2}{*}{ JL. Raya Beji } & 0,58 & C & 0,33 & B & 0,27 & B \\
& 0,70 & C & 0,46 & C & 0,44 & B \\
Jl. Yonkav & 0,12 & A & 0,07 & A & 0,09 & A \\
& 0,13 & A & 0,07 & A & 0,10 & A \\
\hline
\end{tabular}

\section{Pembahasan}

Pengaturan di perlintasan sebidang antara jalan raya dengan jalur kereta api dimana melibatkan arus kendaraan bermotor pada satu sisi dan arus kereta api pada sisi lain menimbulkan permasalahan. Kereta api menggunakan perlintasan dengan 
jadwal tertentu sesuai dengan grafik perjalanan kereta api meskipun kadang tidak tepat waktu, sedangkan kendaraan yang melewati perlintasan tidak terjadwal sehingga arus kendaraan dapat melintasi perlintasan kapan saja. Dari segi akselerasi dan sistem pengereman diperoleh kendaraan bermotor lebih unggul dibandingkan kereta api dimana kendaraan dalam melakukan berakselerasi lebih singkat dari kereta api begitu juga dengan waktu dan jarak pengereman [11].

Berdasarkan survei lapangan dalam satu hari dari pagi (jam 06.00 s.d 10.00), siang hari (10.00 s.d 14.00) dan sore hari (14.00 s.d 18.00) di jalan raya beji arah Surabaya maka diperoleh bahwa jumlah sepeda motor (MC) sebanyak 2799 buah atau sebanyak 41\%, mobil (LV) sebanyak 1391 atau sebanyak $20 \%$ dan bus dan truk (HV) sebanyak 2687 buat atau sebanyak 39\%. Jadi kendaraan melintas dari Jalan Raya Beji ke arah Pasuruan paling banyak adalah sepeda motor, kemudian bus dan truk dan mobil.

Sedangkan dalam satu hari survei dari pagi (jam 06.00 s.d 10.00), siang hari (10.00 s.d 14.00) dan sore hari (14.00 s.d 18.00) diperoleh bahwa jumlah sepeda motor (MC) sebanyak 3362 buah atau sebanyak 34\%, mobil (LV) sebanyak 4448 atau sebanyak 46\% dan bus dan truk (HV) sebanyak 1961 buah atau sebanyak 39\%. Jadi kendaraan melintas dari Jalan Raya Beji ke arah surabaya paling banyak adalah mobil, kemudian sepeda motor, dan bus dan truk. Untuk kendaraan dari jalan raya beji kearah Surabaya yang paling banyal lewat adalah mobil, hal ini berbeda dengan arus sebaliknya atau Jalan Raya Beji ke arah pasuruan dimana mobil menjadi kendaraan yang paling sedikit lewat.

Untuk kendaraan yang melintas dari Jalan Yonkav menuju ke arah Beji dalam satu hari survei dari pagi (jam 06.00 s.d 10.00), siang hari (10.00 s.d 14.00) dan sore hari (14.00 s.d 18.00) diperoleh bahwa diperoleh jumlah sepeda motor (MC) sebanyak 997 buah atau sebanyak 77\%, mobil (LV) sebanyak 277 atau sebanyak $21 \%$ dan bus dan truk (HV) sebanyak 29 buah atau sebanyak 2\%. Jadi kendaraan melintas dari Jalan Yonkav ke arah Beji paling banyak adalah sepeda motor, kemudian mobil, dan bus dan truk.

Untuk kendaraan yang melintas dari Jalan Yonkav ke arah Bangil dalam satu hari survei dari pagi (jam 06.00 s.d 10.00), siang hari (10.00 s.d 14.00) dan sore hari (14.00 s.d 18.00) diperoleh bahwa jumlah sepeda motor (MC) sebanyak 841 buah atau sebanyak $73 \%$, mobil (LV) sebanyak 285 atau sebanyak $25 \%$ dan bus dan truk (HV) sebanyak 23 buah atau sebanyak $2 \%$. Jadi kendaraan melintas dari jalan yonkav kearah bangil paling banyak adalah sepeda motor, kemudian mobil, dan bus dan truk.

Untuk mengukur tingkat pelayanan jalan atau level of service di Jalan Raya Beji arah Pasuruan pada pagi hari jumlah kendaraan total $866,8 \mathrm{smp} / \mathrm{jam}$ dimana untuk V/C sebanyak 0,58 dimana untuk nilai Level of Service (LOS) berada di level $\mathrm{C}$ dimana untuk $\mathrm{D}=\mathrm{V} / \mathrm{C}$ berada diantara 0.45 s.d 0.74 dimana arus stabil, kecepatan dipengaruhi oleh lalu-lintas volume sesuai untuk jalan kota. Pada siang hari jumlah kendaraan 497,2 smp/jam dimana untuk V/C sebanyak 0,33 dimana untuk nilai Level of Service (LOS) berada di level B dimana untuk $\mathrm{D}=\mathrm{V} / \mathrm{C}$ berada diantara 0,20 dan 0,44 dimana arus stabil, kecepatan terbatas, volume sesuai untuk luar kota. Untuk Sore hari jumlah kendaraan 402,4 smp/jam dimana untuk V/C sebanyak 0,27 dimana untuk nilai Level of Service (LOS) berada di level B dimana untuk D=V/C berada diantara 0,20 dan 0,44 dimana arus stabil, kecepatan terbatas, volume sesuai untuk luar kota. 
Jalan Raya Beji arah Surabaya pada pagi hari jumlah kendaraan total 1053 smp/jam dimana untuk V/C sebanyak 0,70 dimana untuk nilai Level of Service (LOS) berada di level $\mathrm{C}$ dimana untuk $\mathrm{D}=\mathrm{V} / \mathrm{C}$ berada diantara 0.45 s.d 0.74 dimana arus stabil, kecepatan dipengaruhi oleh lalu-lintas volume sesuai untuk jalan kota. Pada siang hari jumlah kendaraan 693 smp/jam dimana untuk V/C sebanyak 0,46 dimana untuk nilai Level of Service (LOS) berada di level C dimana untuk D=V/C berada diantara 0.45 s.d 0.74 dimana arus stabil, kecepatan dipengaruhi oleh lalulintas volume sesuai untuk jalan kota. Untuk Sore hari jumlah kendaraan 660,3 smp/jam Dengan demikian maka untuk dimana untuk V/C sebanyak 0,44 dimana untuk nilai Level of Service (LOS) berada di level B dimana untuk D=V/C berada diantara 0,20 dan 0,44 dimana arus stabil, kecepatan terbatas, volume sesuai untuk luar kota.

Jalan Yonkav arah Bangil pada pagi hari jumlah kendaraan total $85 \mathrm{smp} / \mathrm{jam}$ dimana untuk V/C sebanyak 0,12 dimana untuk nilai Level of Service (LOS) berada di level A dimana untuk $\mathrm{D}=\mathrm{V} / \mathrm{C}$ berada diantara 0.00 s.d 0.19 dimana arus lancar, volume rendah dan kecepatan tinggi. Pada siang hari jumlah kendaraan $52 \mathrm{smp} / \mathrm{jam}$ dimana untuk V/C sebanyak 0,07 dimana untuk nilai Level of Service (LOS) berada di level A dimana untuk $\mathrm{D}=\mathrm{V} / \mathrm{C}$ berada diantara 0.00 s.d 0.19 dimana arus lancar, volume rendah dan kecepatan tinggi. Untuk Sore hari jumlah kendaraan 65.6 smp/jam dimana untuk V/C sebanyak 0,09 dimana untuk nilai Level of Service (LOS) berada di level A dimana untuk $\mathrm{D}=\mathrm{V} / \mathrm{C}$ berada diantara 0.00 s.d 0.19 dimana arus lancar, volume rendah dan kecepatan tinggi

Jalan Yonkav arah Bangil pada pagi hari jumlah kendaraan total $95.1 \mathrm{smp} / \mathrm{jam}$ dimana untuk V/C sebanyak 0,13 dimana untuk nilai Level of Service (LOS) berada di level A dimana untuk $\mathrm{D}=\mathrm{V} / \mathrm{C}$ berada diantara 0.00 s.d 0.19 dimana arus lancar, volume rendah dan kecepatan tinggi. Pada siang hari jumlah kendaraan 49.1 smp/jam dimana untuk V/C sebanyak 0,07 dimana untuk nilai Level of Service (LOS) berada di level A dimana untuk $\mathrm{D}=\mathrm{V} / \mathrm{C}$ berada diantara 0.00 s.d 0.19 dimana arus lancar, volume rendah dan kecepatan tinggi. Untuk Sore hari jumlah kendaraan $70 \mathrm{smp} / \mathrm{jam}$ dimana untuk V/C sebanyak 0,10 dimana untuk nilai Level of Service (LOS) berada di level A berada diantara 0.00 s.d 0.19 dimana arus lancar, volume rendah dan kecepatan tinggi.

Dikaitkan dengan hasil penelitian di perlintasan jalan Padang Medan Tembung dimana perlintasan tersebut tidak memenuhi standar teknis perlintasan kereta api tanpa palang pintu. Juga tanpa adanya pengamanan pada saat kereta api melintas, pengamanan hanya suara sirine dari kereta api yang berfungsi sebagai tanda kepada pengguna jalan yang melintas. Hasil analisis terhadap kapasitas jalan bahwa perlintasan tersebut masih dibawah dari standart teknis yang ditentukan, oleh karena itu perlintasan kereta api jalan Padang masih memenuhi syarat sebagai perlintasan sebidang [12]. Keadaan ini karakteristinya hampir sama dengan perlintasan sebidang resmi tidak di jaga di jalan Beji Raya dan Jalan Yonkav.

Selain itu berdasarkan ketentuan pasal 2 dalam PM No 94 tahun 2018 tentang Peningkatan Keselamatan Perlintasan Sebidang antara Jalan Kereta Api dengan jalan maka jalan Yonkav arah Beji dan arah Bangil merupakan Jalan Kabupaten Pasuruan, sedangkan Jalan Raya Beji arah Surabaya dan arah Pasuruan merupakan jalan nasional. Hal ini hampir mirip dengan Jalan Kaligawe dan Kaliwungu di semarang dimana terdapat ketidaksamaan secara geometrik dan jenis kendaraan yang melewatinya. Jalan Kaligawe tipe 4/2D dilewati semua jenis kendaraan, 
sedangkan Jalan Kaliwungu tipe 2/2UD yang didominasi kendaraan ringan. Perbedaan tersebut mengakibatkan tingkat arus kendaraan (flow) dan kapasitas jalan menjadi berbeda, yang kemudian berpengaruh terhadap kinerja lalu lintas dan pengaruh penutupan pintu perlintasaan berupa panjang antrian dan waktu kendaraan kembali normal. [13].

Dari hasil survei di dapatkan bahwa untuk Jalan Yonkav arah Bangil atau Beji untuk Level of Service masih berada di level A semua setiap harinya, dimana kendaraan yang melintas dimana arus lancar, volume rendah dan kecepatan tinggi. Sedangkan untuk Jalan Raya Beji arah Surabaya pada pagi hari dan siang hari dengan level of service berada di level $\mathrm{C}$ dimana arus stabil, kecepatan dipengaruhi oleh lalu-lintas volume sesuai untuk jalan kota dan arah ke pasuruan pada pagi hari level of service juga berada di level C. Sedangkan untuk siang hari dan sore hari berada di level B dimana arus stabil, kecepatan terbatas, volume sesuai untuk luar kota. Berdasarkan penelitian mengenai pengguna jalan di perlintasan sebidang resmi tidak di jaga di Jalan Grogol Kabupaten Tegal didapatkan hasil bahwa pelanggaran pengguna jalan yang melintas di perlintasan sebidang kereta api berupa tindakan melanggar rambu lalu lintas. Selain itu pada saat tidak ada kereta api yang melintas, pengguna jalan terlihat tidak memperlambat laju kendaraan atau mengurangi kecepatan saat akan melewati rel dan tidak menengok ke kanan dan ke kiri untuk memastikan bahwa tidak ada kereta yang melintas sehingga aman dan selamat. Selain itu pengguna jalan pada saat melintas rel beberapa diantaranya ada yang mendahului pengguna jalan lainnya khususnya kendaraan sepeda motor.[14]. Pada penelitian ini tidak melakukan pengamatan terhadap perilaku pengguna jalan yang melintas di Jalan Beji Raya dan Jalan Yonkav, namun berdasarkan hasil penelitian tersebut bisa dijadikan gambaran tentang perilaku dari penggendara jalan pada saat melintas di perlintasan sebidang resmi tidak di jaga.

Berdasarkan pasal 124 dan pasal 125 Undang-undang No 23 Tahun 2007 tentang Perkeretaapian maka pengguna jalan raya harus mengutamakan kereta api untuk lewat terlebih dahulu dibandingkan pengguna jalan raya [15]. Selain itu berdasarkan penelitian di perlintasan sebidang di Surabaya maka didapatkan hasil bahwa peningkatan volume kendaraan menyebabkan kemacetan di beberapa titik. Salah satu faktor penyebab kemacetan di perlintasan adalah durasi waktu penutupan saat kereta melewati persimpangan. Durasi penutupan perlintasan yang tidak pasti menyebabkan pengguna jalan menjadi tidak disiplin dengan menerobos perlintasan yang berakibat pada meningkatnya tingkat kecelakaan lalu lintas yang terjadi di perlintasan sebidang tidak berpalang pintu hal ini dikarenakan pengguna jalan akan memilih jalur lainnya di perlintasan tanpa palang pintu. [16].

Hal ini sesuai dengan studi simulasi di Brisbane Australia telah menemukan bahwa variabilitas waktu peringatan yaitu yang terjadi antara aktivasi lampu peringatan sampai kereta tiba di perlintasan sebidang adalah penyebab utama dari perlintasan yang belum saatnya palang persimpangan menutup, diperlukan penghematan waktu peringatan yang dapat dicapai untuk operasi pergerakan pintu perlintasan rata-rata adalah 10-40 detik. [17].

Berdasarkan olah data dilapangan tersebut maka untuk mengatasi terjadinya kejadian yang tidak diinginkan di perlintasan sebidang resmi tidak dijaga di Jalan Yonkav perlu dilakukan solusi yang terdiri dari solusi jangka pendek, solusi jangka menengah dan solusi jangka panjang antara lain [18] :

1. Solusi jangka pendek 
a. Pemasangan rambu-rambu untuk perlintasan sebidang harus sesuai dengan peraturan yang berlaku.

b. Memberikan sosialisasi kepada penduduk setempat agar mengutamakan keselamatan dengan memperlambat kendaraan serta menengok ke kanan dan ke kiri pada saat hendak melintasi perlintasan sebidang dan mengutamakan kereta api untuk melintas dahulu daripada kendaraan lainnya.

c. Mengecek secara rutin Early Warning System (EWS) agar selalu berfungsi sehingga mampu memberikan peringatan bagi pengguna jalan yang melintasi perlintasan sebidang.

2. Solusi jangka menengah

a. Mengaktifkan jalan-jalan yang berhubngan dengan jalan rel kereta api agar dapat menguraikan dan mengurangi kemacetan di jalan lokasi perlintasan sebidang.

b. Melakukan evaluasi Bersama antara unit kerja terkait yang terdiri atas Direktorat Jenderal Perkeretaapian, Direktorat Jenderal Perhubungan Darat, Dinas Perhubungan, Dinas Bina Marga, Kepolisian Negara Republik Indonesia, dan Daop/Divre PT. Kereta Api Indonesia (Persero) yang berperan dalam keselamatan di perlintasan sebidang resmi tidak dijaga di Jalan Yonkav. (Kemenhub, 2018).

c. Perlu adanya penjaga perlintasan sebidang (PJL) dan perlintasan sebidang resmi di jaga (JPL). Namun perlu juga diperhitungkan terkait jika nanti adanya palang pintu perlintasan sebidang karena durasi penutupan pintu perlintasan kereta api memberi pengaruh yang signifikan pada waktu terjadinya tundaan dan Panjang antrian kendaraan di masing-masing lajur pendekat.[19]

d. Pengaplikasian perlintasan sebidang yang terhubung dengan lampu lalu-lintas (APIL).

3. Solusi jangka panjang

a. Berdasarkan hasil perhitungan didapatkan bahwa di jalan nasional yaitu Jalan Raya Beji arah Surabaya ataupun arah Pasuruan sudah dalam kondisi kepadatan lalu-lintas yang cukup tinggi apalagi pada saat pagi hari antara pukul 06.00 s.d 10.00, serta mempertimbangkan peningkatan dan perkembangan Kabupaten Pasuruan maka beberapa tahun ke depan mungkin akan terjadi kemacetan sehingga memerlukan solusi berupa dibuatnya geometri yang miring dari jalan Raya Beji arah Surabaya ataupun Pasuruan sehingga ketika pengguna jalan membelok ke perlintasan sebidang akan ada waktu lebih banyak untuk memperlambat laju kendaraannya dan ada waktu untuk menengok ke kanan dan ke kiri apabila Early Warning System (EWS) tidak berbunyi.

b. Solusi jangka panjang lainnya dengan membuat fly over atau underpass di perlintasan sebidang resmi tidak dijaga di Jalan Yonkav dan Jalan Raya Beji.

\section{PENUTUP}

Perlintasan sebidang resmi tidak dijaga di Jalan Beji Raya dan Jalan Yonkav sebagaimana perlintasan sebidang lainnya sering kali terdapat masalah. Karakteristik utama dari perlintasan tersebut adalah karena tidak ada palang pintu dan tidak ada penjaga perlintasan sebidang, selain itu juga Jalan Raya Beji merupakan jalan nasional dimana pada pagi hari pada saat jam sibuk Level of 
Service (LOS) berada di Level C, sedangkan jalan Yonkav merupakan jalan kabupaten dimana Level Of Service (LOS) berada di level A baik pada pagi, siang ataupun sore hari. Banyaknya kecelakaan yang terjadi di perlintasan sebidang resmi tidak dijaga tersebut selain faktor arus lalu-lintas kendaraan yang melintasi perlintasan juga perlu diperhatikan faktor perilaku dari pengguna jalan yang tidak mau menenggok ke kanan dan kiri kearah perlintasan datangnya kereta api, perilaku pengguna jalan yang tidak mau menunggu atau bahkan menyalip pengguna jalan lainnya, dan juga pengguna jalan yang bukan penduduk asli setempat sehingga tidak mengenal medan di perlintasan tersebut. Untuk mengatasi permasalahan tersebut dikarenakan perlintasan sebidang resmi tidak dijaga itu berada di antara jalan nasional dan jalan kabupaten maka perlu duduk bersama antara pemerintah pusat, pemerintah propinsi, pemerintah daerah selaku pembuat kebijakan beserta penyelenggara perkeretaapian umum selaku operator untuk mengimplementasikan solusi jangka pendek, solusi jangka menengah dan juga solusi jangka panjang di perlintasan sebidang resmi tidak dijaga Jalan Raya Beji dan Jalan Raya Yonkav.

\section{Saran}

Peneliti berikutnya dapat menyertakan tundaan di perlintasan sebidang agar dapat memberikan solusi dan menganalisis permasalahan di perlintasan sebidang Jalan Yonkav dan Jalan Raya Beji agar dapat memberikan solusi yang lebih akurat, dikarenakan pada saat survei lapangan sedang dalam masa PPKM dikarenakan adanya pandemi Covid-19.

\section{DAFTAR PUSTAKA}

[1] Menteri Perhubungan Republik Indonesia, PM No 94 Tahun 2018 tentang Peningkatan Keselamatan Perlintasan Sebidang Antara Jalur Kereta Api Dengan Jalan. Indonesia: JDIH Kemenhub, 2018.

[2] B. K. Pasuruan, Keputusan Bupati Pasuruan No. 950/397/HK/424.014/2017 Tentang Penetapan Status Ruas-Ruas Jalan Sebagai Jalan Kabupaten di Kabupaten Pasuruan. Indonesia: Pemerintah Daerah Kabupaten Pasuruan, 2017.

[3] B. K. PUPR, "Modul 3 : Dasar-Dasar Perencanaan Geometrik Ruas Jalan," in Modul, Badan Pengembangan Sumber Daya Manusia kementerian PUPR, 2017, p. 7.

[4] F. P. Luthfiyani and E. Ahyudanari, "Karakteristik Pengemudi Sepeda Motor Dalam Model Peluang Kecelakaan (Studi Kasus: Perlintasan Sebidang di Jalur Perlintasan Langsung (JPL) 325 Lamongan)," J. Apl. Tek. Sipil, vol. 19, no. 2, p. 151, 2021, doi: 10.12962/j2579-891x.v19i2.8627.

[5] M. R. Sandi Nurhartanto, "Mitsubisi L300 Tertabrak KA Jayabaya, Lima Orang Meninggal Dunia," Jatimnews.com, p. https://jatimnow.com/baca10990-mitsubisi-1300-ter, 2019.

[6] N. Richfidel, N. Wie, L. I. R. Lefrandt, and S. V Pandey, "Kajian Efektifitas Penerapan Zona Selamat Sekolah (ZoSS) Di Kota Tomohon (Studi Kasus : SD Negeri 2 Tomohon Dan SD Lentera Harapan Tomohon)," J. Sipil Statik, vol. 7, no. ISSN: 2337-6732, p. 229, 2019.

[7] E. K. Morlok, Pengantar teknik dan Perencanaan Transportasi. PT Erlangga, 1995.

[8] Direktorat Jenderal Perhubungan Darat, Peraturan Direktur Jenderal Perhubungan Darat Nomor SK.770/KA.401/DRJD/2005 tentang Pedoman 
Teknis Perlintasan Sebidang Antara Jalan dengan Jalur Kereta Api. 2005, pp. $1-53$.

[9] P. K. (Persero), "KAI Jadwal Perjalanan Kereta Api 2021," Web PT KAI (Persero) Indonesia, p. 56, 2021.

[10] Departemen Pekerjaan Umum, Highway Capacity Manual Project (HCM), vol. 1, no. I. 1997.

[11] Y. Aswad, "Studi Kelayakan Perlintasan Sebidang antara Jalan Kereta Api dengan Jalan Raya," pp. 183-189, 2015.

[12] D. T. Asfiati, Sri Mutiara, "Studi Keselamatan dan Keamanan Transportasi di Perlintasan Sebidang Antara Jalan Rel dengan Jalan Umum ( Studi Kasus Perlintasan Kereta Api Di Jalan Padang, Bantan Timur, Kecamatan Medan Tembung )," vol. 2, no. 1, pp. 31-41, 2020.

[13] M. Yusyadiputra, R. Hermawanto, B. Pudjianto, and E. Yulipriyono, "Pengaruh Penutupan Pintu Perlintasan Jalan Rel Terhadap Kinerja Lalu Lintas Jalan Raya Di Perlintasan Kaligawe Semarang Dan Kaliwungu Kendal," J. Karya Tek. Sipil, vol. 3, no. 3, pp. 723-735, 2014.

[14] I. F. Y. Anton Budiharjo, "Kajian Peningkatan Keselamatan Perlintasan Sebidang Kereta Api Grogol Di Kabupaten Tegal Study On Improving The Safety Of The Crossroads Of The Grogol Railway In The Tegal Regency," $J$. Keselam. Transp. Jalan (Indonesian J. Road Safety), vol. 6, no. 2, pp. 15-37, 2019, doi: 10.46447/ktj.v6i2.30.

[15] Menteri Perhubungan Indonesia, Undang-Undang Nomor 23 tahun 2007 tentang Perkeretaapian. Indonesia: JDIH Kemenhub, 2007.

[16] A. Utami and H. Widyastuti, "Model Panjang Antrian Kendaraan pada Perlintasan Sebidang Tanpa Palang Pintu (Studi Kasus: Perlintasan Sebidang Jl. Gayung Kebonsari Surabaya)," J. Apl. Tek. Sipil, vol. 17, no. 1, p. 27, 2019, doi: 10.12962/j2579-891x.v17i1.4693.

[17] G. S. Larue et al., "Can road user delays at urban railway level crossings be reduced? Evaluation of potential treatments through traffic simulation," Case Stud. Transp. Policy, vol. 8, no. 3, pp. 860-869, 2020, doi: 10.1016/j.cstp.2020.05.016.

[18] Hartono, "Perlintasan Sebidang Kereta Api Di Kota Cirebon Level Crossing Railways In Cirebon," J. Penelit. Transp. darat, Balitbang Kemenhub, vol. 18, no. 1, p. 45, 2017.

[19] Andi Syaiful Amal, "Pengaruh Penutupan Pintu Perlintasan kereta Api Terhadap Tundaan dan Panjang Antrian Kendaraan Pada Jalan Raya Malang - Surabaya KM. 10," 2003. 